\title{
RISK ASSESSMENT KECELAKAAN KERJA PADA PENGOPERASIAN BOILER DI PT. INDONESIA POWER UNIT PEMBANGKITAN SEMARANG
}

\author{
Eliza Marceliana Zeinda, Sho'im Hidayat \\ Departemen Keselamatan dan Kesehatan Kerja \\ Fakultas Kesehatan Masyarakat, Universitas Airlangga Surabaya \\ Email: Elzozo.marcel@gmail.com
}

\begin{abstract}
Boiler is a tool produced steam. The operation of boiler produce hazard that can cause accidents in labor. The purpose of this research is to risk assessment for accidents work in the operation of boilers in PT. Indonesia Power Unit Pembangkitan Semarang. This research is observational. The object of this research is boiler. The subject of this research is coordinator and operator boiler. The primary data was obtained from observation and interview, while secondary data from the corporate documents. The result showed that boilers in PT. Indonesia Power Unit Pembangkitan Semarang were 3 unit of water tube using fuel MFO and HSD. The identification hazard obtained 12 findings hazard on 9 areas the operation boiler PT. Indonesia Power unit Pembangkitan Semarang. The hazard in the area of boiler are noise, hot weather, fire sparks, hit, pinched hand, discover water vapor, high pressure, electricity, contact with a steam pipe, amount of oil, exposed $\mathrm{NaOH}$ liquid, and slip and fall down from the height. On controlling value, there were 6 hazards that classified as in very good control, 3 hazards were classified as partly implemented, and 3 hazards were classified as implemented. The residual risk was obtained 5 category risk with no risk and 7 risk categories low. Conclusion that can be drawn are hazard boiler in PT. Indonesia Power Unit Pembangkitan Semarang have high risk of are hazard discover water vapor and the high pressure. The company suggested to perform maintenance and reduce the risk to a low.
\end{abstract}

Keywords: risk assessment, work accidents, boiler

\begin{abstract}
ABSTRAK
Boiler adalah alat penghasil uap. Pada pengoperasian boiler menghasilkan bahaya yang dapat menimbulkan kecelakaan pada tenaga kerja. Tujuan penelitian adalah melakukan risk assessment terhadap kecelakaan kerja pada pengoperasian boiler di PT. Indonesia Power Unit Pembangkitan Semarang. Penelitian ini adalah penelitian observasional. Objek penelitian ini adalah boiler. Subjek penelitian ini adalah koordinator dan operator boiler. Data primer diperoleh dari observasi dan wawancara, sedangkan data sekunder dari dokumen perusahaan. Hasil penelitian menunjukkan bahwa boiler di PT. Indonesia Power Unit Pembangkitan Semarang berjumlah 3 unit jenis pipa air menggunakan bahan bakar MFO dan HSD. Hasil identifikasi bahaya diperoleh 12 temuan bahaya pada 9 area pengoperasian boiler PT. Indonesia Power Unit Pembangkitan Semarang. Temuan bahaya di area pengoperasian boiler adalah kebisingan, cuaca panas, percikan api, terbentur, tangan terjepit, bocoran uap air, tekanan tinggi, arus listrik, kontak dengan pipa uap air yang panas, ceceran minyak, terkena cairan $\mathrm{NaOH}$, dan terpeleset dan terjatuh dari ketinggian. Pada pengendalian risiko terdapat 6 bahaya kategori nilai kontrol sangat baik, 3 bahaya kategori nilai kontrol diimplementasikan dengan baik, dan 3 bahaya kategori nilai kontrol diimplementasikan dengan cukup baik. Penilaian risiko sisa didapatkan 5 risiko dengan kategori tidak ada risiko dan 7 risiko kategori rendah. Kesimpulan penelitian adalah bahaya boiler di PT. Indonesia Power Unit Pembangkitan Semarang yang mempunyai risiko tinggi adalah bahaya bocoran uap air dan tekanan tinggi. Perusahaan disarankan untuk melakukan maintenance dan mengurangi kemungkinan risiko sampai batas rendah.
\end{abstract}

Kata kunci: risk assessment, kecelakaan kerja, boiler

\section{PENDAHULUAN}

Boiler merupakan alat yang berfungsi untuk menghasilkan uap sebagai penggerak turbin. Air yang digunakan untuk bahan dasar penghasil uap di boiler harus air murni. Bahan bakar dan udara merupakan sumber energi yang digunakan untuk mengubah wujud dari cair menjadi uap bertekanan tinggi (Fauzy dan Rusdhianto, 2012).

Ada tiga proses pada boiler yang cukup kompleks, yaitu proses air umpan, proses bahan bakar, dan proses uap air (Kristianingsih dan Ali, 2013). Boiler mempunyai risiko bahaya, seperti 
tergelincir atau terjatuh, ledakan, kebakaran, iklim kerja, kebisingan, dan defisiensi oksigen (Veasey, 2002).

Di Indonesia terdapat beberapa kasus mengenai kecelakaan kerja pada boiler. Kebanyakan kasus yang terjadi di Indonesia disebabkan dari perusahaan kecil, namun perusahaan besar pun turut menyumbang kasus kecelakaan yang disebabkan oleh boiler. Kasus ledakan yang pernah terjadi di perusahaan kecil dikutip dari Fatoni (2013), di antaranya pabrik kerupuk di Kaliwates, Jember, Mei 2001 menewaskan 4 orang, dan pabrik tahu di Taman, Sidoarjo, Januari 2005 menewaskan 2 orang. Kasus kebocoran lubang yang dilalui orang dan kegagalan sensor api di PT. Japfa Comfeed Indonesia Tbk Unit Gedangan (Rahadiyan, 2014).

Undang-undang uap Tahun 1930 dan Undangundang No. 1 Tahun 1970 Tentang Keselamatan Kerja bahwa perusahaan yang menggunakan boiler wajib menyelenggarakan program K3, agar dapat mengurangi jumlah kecelakaan yang akan timbul. Perusahaan memerlukan tindakan keselamatan dan kesehatan kerja dalam bidang pekerjaannya. Tindakan keselamatan dan kesehatan kerja dengan menerapkan manajemen risiko. Salah satu komponen dari manajemen risiko adalah risk assessment. Tahapan risk assessment adalah identifikasi bahaya, penilaian risiko, pengendalian risiko dan penilaian risiko sisa.

PT. Indonesia Power Unit Pembangkitan Semarang merupakan salah satu perusahaan pembangkitan listrik di Indonesia. PT. Indonesia Power Unit Pembangkitan Semarang mempunyai tiga jenis pembangkit, yaitu PLTU, PLTG, dan PLTGU dengan total kapasitas 1469 MW. Pada proses produksi pembangkit listrik PT. Indonesia Power unit Pembangkitan Semarang, boiler merupakan salah satu mesin yang penting. Kasus yang pernah dialami pada PT. Indonesia Power Unit Pembangkitan Semarang yaitu kerusakan pada pipa karena korosi yang menyebabkan kebocoran pada pipa.

Kasus tersebut dapat menjadi kerugian bagi perusahaan. Oleh karena itu, perlu mengetahui risiko apa saja yang dapat ditimbulkan dari proses pengoperasian boiler dengan cara melakukan tindakan identifikasi bahaya pada proses pengoperasian boiler dan dilakukan penilaian risiko untuk mengetahui tingkat risiko dari bahaya yang telah teridentifikasi. Setelah melakukan penilaian risiko maka risiko tersebut dapat dikendalikan dengan baik.
Tujuan dari penelitian ini adalah melakukan risk asessment pada kecelakaan kerja pengoperasian boiler di PT. Indonesia Power Unit Pembangkitan Semarang.

\section{METODE}

Berdasarkan pengumpulan data, penelitian ini termasuk penelitian observasional. Berdasarkan waktu, penelitian ini termasuk penelitian cross sectional. Penelitian ini dilakukan di PT. Indonesia Power Unit Pembangkitan Semarang. Penelitian dilakukan pada periode bulan Maret tahun 2016. Objek penelitian adalah pekerjaan pengoperasian boiler di PT. Indonesia Power Unit Pembangkitan Semarang. Subjek penelitian adalah seluruh pekerja pada pengoperasian boiler, yaitu 24 operator, koordinator atau supervisor yang bertanggung jawab pada pengoperasian boiler di PT. Indonesia Power Unit Pembangkitan Semarang.

Data primer diperoleh dengan melakukan wawancara menggunakan lembar pertanyaan dan observasi langsung pada pengoperasian boiler dan lingkungan kerja dengan pengambilan gambar dan melakukan catatan dilembar observasi. Data sekunder berasal dari dokumen perusahaan. Variabel yang diteliti adalah bahaya yang terdapat pada proses pengoperasian boiler beserta upaya pengendalian.

Tahapan pelaksanaan pertama adalah melakukan identifikasi potensi bahaya kecelakaan kerja pada pengoperasian boiler. Selanjutnya dilakukan penilaian risiko dengan menentukan likelihood dan severity dan dilakukan perkalian untuk menentukan tingkatan risiko berdasarkan standar AS/NZS 4360. Detail pengendalian diperoleh dari observasi langsung dan wawancara. Data akan dianalisis secara deskriptif dengan penjabaran hasil temuan dari observasi di lapangan dalam bentuk tabel dan narasi. Hasil analisis juga akan digunakan sebagai kesimpulan dari penelitian.

\section{HASIL}

PT. Indonesia Power Unit Pembangkitan Semarang mempunyai 3 unit boiler dengan kapasitas $50 \mathrm{MW}$ pada unit 1 dan 2, dan kapasitas $200 \mathrm{MW}$ pada unit 3. Ke tiga unit boiler menggunakan bahan bakar MFO (Marine Fuel Oil) yang dialirkan melalui kapal tongkang dan dipompa untuk menuju tangki bahan bakar minyak. Ke tiga unit boiler merupakan jenis pipa air (water tube boiler) karena pipa boiler berisikan air dan api berada di luar pipa. Boiler jenis 
pipa air umumnya digunakan oleh perusahaan besar yang membutuhkan tekanan dan kapasitas yang tinggi dalam produksinya.

Bahan bakar MFO merupakan produk penyulingan minyak bumi setelah residu dan sebelum aspal. Sifat yang dimiliki dari bahan bakar MFO yaitu cenderung menggumpal seperti aspal. Pengoperasian boiler di PT. Indonesia Power Unit Pembangkitan Semarang membutuhkan bahan bakar bantu berupa HSD (High Speed Diesel). Tujuan dari bahan bakar bantu HSD adalah menaikkan suhu pada pengoperasian awal dan penstabilan pembakaran pada boiler. Bahan bakar MFO tidak bisa langsung digunakan sehingga nilai kekentalannya harus diturunkan dengan cara melakukan pemanasan terlebih dahulu. Bahan bakar HSD tidak membutuhkan pemanasan saat digunakan. Bahan bakar HSD disemprotkan di ruang bakar, lalu pada saat ruang bakar telah mencapai suhu tertentu, maka bahan bakar HSD diganti dengan bahan bakar MFO. Bahan bakar MFO akan dispray dan dikabutkan di ruang bakar.

Pada sirkulasi air boiler, air akan dipompa menuju boiler menggunakan boiler feed pump. Air akan dipanaskan terlebih dahulu di tiga tempat, yaitu di low pressure heater, dipanasi lagi di high pressure heater, dan terakhir dipanasi juga di economizer. Tujuan dari air dipanaskan terlebih dahulu agar temperatur air mendekati titik didih air sebelum air tersebut akan masuk ke dalam steam drum boiler. Di dalam drum boiler, air akan dipanaskan kembali sehingga terbentuklah uap air. Uap dan air yang berada pada riser akan naik dan air yang berada dalam pipa down comer akan turun. Uap yang dihasilkan dari pemanasan akan dialirkan melalui pipa superheater menuju turbin. Sirkulasi air boiler ini terjadi secara alami.

Tahapan alur pengoperasian pada boiler yang pertama adalah penyaringan air laut yang dilakukan oleh tiga penyaring, yaitu bar screen, travelling screen, dan debris filter. Setelah air disaring, air akan diberikan zat klorin sebagai desinfektan. Air akan dipompa dan dialirkan menuju dua tempat, yaitu sebagai pendingin di kondenser, dan akan menuju ke desalination evaporator untuk diubah menjadi air tawar. Air yang telah berubah menjadi air tawar akan diubah menjadi air murni dengan penambahan resin kation dan anion. Air murni tersebut akan dipompa dan dialirkan ke dalam dua buah low pressure heater. Air dialirkan lagi ke deaerator untuk menghilangkan kandungan gas di dalamnya. Air dipompa kembali ke high pressure heater dan dipanaskan juga oleh ekonomiser. Air yang sudah dipanaskan dengan suhu yang diinginkan tersebut masuk ke dalam drum uap. Drum uap akan dihasilkan uap dengan cara pemasakan. Uap yang dihasilkan drum uap masih merupakan uap basah, sehingga uap tersebut dipanaskan lagi di pipa superheater dan menghasilkan uap kering. Uap kering akan dialirkan ke turbin, sedangkan uap bekas akan didinginkan pada kondensat dan bersatu dengan air demin dan masuk kembali ke boiler.

\section{Identifikasi Bahaya}

Tahapan pertama untuk mengetahui penyebab terjadinya kecelakaan kerja pada pengoperasian boiler yaitu dengan melakukan identifikasi bahaya. Adapun hasil dari identifikasi bahaya pada area pengoperasian boiler dijelaskan pada 9 pengoperasian, yaitu firing boiler, pengoperasian peralatan boiler, Pengoperasian Force Draft Fan/ Gas Recirculation Fan, pengoperasian pompa BBM, pengisian air boiler, pengoperasian burner, pengoperasian kimia, pengoperasian soot blower, dan pencatatan parameter. Berikut adalah identifikasi bahaya pada area pengoperasian boiler di PT. Indonesia Power Unit Pembangkitan Semarang.

Hasil identifikasi bahaya pada area proses pengoperasian boiler di PT. Indonesia Power Unit Pembangkitan Semarang adalah sebanyak 9 pengoperasian dengan 12 potensi bahaya. Potensi bahaya di boiler antara lain:

Kebisingan dapat diakibatkan dari aktivitas seperti pengoperasian peralatan boiler, Pengoperasian Force Draft Fan/Gas Recirculation Fan, dan pengisian air boiler. Bahaya kebisingan yang berada di pengoperasian boiler termasuk kebisingan kontinyu. Dampak yang diakibatkan dari kebisingan berupa ketulian. Apabila kebisingan dengan intensitas yang tinggi secara terus menerus dalam waktu yang lama dapat mengakibatkan penurunan daya pendengaran (Rambe, 2003). Hasil pengukuran intensitas kebisingan di PT. Indonesia Power Unit Pembangkitan Semarang menunjukkan antara 80-100 dBA dalam waktu kerja 8 jam kerja. Pekerja menggunakan APT (Alat Pelindung Telinga) selama bekerja.

Cuaca panas dihasilkan dari aktivitas firing boiler. Cuaca panas dapat menimbulkan dehidrasi karena bekerja di lingkungan yang panas menyebabkan tubuh banyak mengeluarkan keringat. Hasil wawancara suhu udara yang paling tinggi adalah $35^{\circ} \mathrm{C}$. Pekerja tidak selalu terpapar dengan suhu udara tersebut, karena terdapat ruang kontrol 
Tabel 1. Identifikasi Risiko pada Pengoperasian Boiler

\begin{tabular}{lll}
\hline \multicolumn{1}{c}{ Langkah Pekerjaan } & \multicolumn{1}{c}{ Potensi Bahaya } & \multicolumn{1}{c}{ Risiko } \\
\hline Firing Boiler & Cuaca panas & Dehidrasi \\
& Ceceran minyak & Tuli \\
Pengoperasian Peralatan Boiler & Kebisingan & Ledakan \\
& Tekanan tinggi & Luka bakar \\
& Kontak dengan pipa uap air yang panas & Tuli \\
Pengoperasian Force Draft Fan/Gas Recirculation Fan & Kebisingan & Kesetrum \\
& Arus Listrik & Cedera \\
Pengoperasian Pompa BBM & Tangan terjepit & Terpeleset \\
Pengisian Air Boiler & Ceceran minyak & Tuli \\
Pengoperasian Burner & Kebisingan & Kebakaran \\
Pengoperasian Kimia & Percikan Api & Korosi \\
Pengoperasian Soot Blower & Terkena cairan NaOH & Luka bakar \\
Pencatatan Parameter & Bocoran uap air & Cedera \\
& Terbentur & Cedera \\
\hline
\end{tabular}

yang ber-AC yang dapat memantau semua aktivitas boiler dan pekerja tidak perlu untuk selalu berada di dekat pengapian.

Ceceran minyak ditimbulkan dari firing boiler dan pengoperasian pompa-pompa BBM. Ceceran minyak dapat berisiko terpeleset. Berdasarkan hasil observasi, terdapat pekerja cleaning service yang selalu membersihkan lantai dan peralatan.

Tekanan tinggi dapat ditimbulkan dari pengoperasian peralatan boiler. Bahaya tekanan tinggi dapat menyebabkan ledakan sehingga proses produksi akan berhenti dan dapat mengancam keselamatan pekerja. Dari data sekunder, pipa boiler pernah mengalami kebocoran dan kerusakan. Bahaya tekanan tinggi dapat dikendalikan dengan pengendalian teknik berupa safety valve.

Kontak dengan pipa uap air yang panas dapat menimbulkan luka bakar. Bahaya ini dapat timbul dari aktivitas pengoperasian peralatan boiler. Pipa uap air yang bertemperatur lebih dari $500^{\circ} \mathrm{C}$ dapat mengancam keselamatan pekerja. Namun bahaya ini dapat dikendalikan dengan penggunaan APD.

Bahaya arus listrik dapat menimbulkan risiko kesetrum. Bahaya arus listrik berasal dari aktivitas Pengoperasian Force Draft Fan/Gas Recirculation Fan. Berdasarkan hasil observasi, kabel-kabel sudah terbungkus oleh isolator dan tidak ada kabel yang terkelupas.

Bahaya tangan terjepit didapatkan dari aktivitas force draft fan/gas recirculation fan. Bahaya tangan terjepit dapat mengakibatkan cedera bagi pekerja. Berdasarkan hasil observasi dan wawancara, terdapat SOP dalam pengoperasian boiler dan terdapat kotak P3K di setiap ruang kontrol.
Percikan api yang ditimbulkan dari aktivitas pengoperasian burner dapat mengakibatkan kebakaran. Bahan bakar yang digunakan oleh boiler PT. Indonesia Power Unit Pembangkitan Semarang adalah bahan bakar MFO yang tidak mudah terbakar, sehingga apabila terjadi kebakaran maka dapat dikendalikan dengan cepat dan tidak menimbulkan korban.

Bocoran uap air ditimbulkan dari aktivitas pengoperasian soot blower. Bocoran uap air yang bertemperatur lebih dari $500^{\circ} \mathrm{C}$ dapat mengancam keselamatan pekerja. Berdasarkan data sekunder, pipa superheater pernah mengalami kebocoran namun belum menimbulkan kecelakaan pada pekerja.

Bahaya terbentur dari aktivitas pencatatan parameter dapat mengakibatkan pekerja cedera. Cedera yang mungkin dialami oleh pekerja dapat berupa memar sampai kepala bocor. PT. Indonesia Power Unit Pembangkitan Semarang menyediakan APD berupa safety helmt untuk menghindari bahaya terbentur tersebut.

Cairan $\mathrm{NaOH}$ merupakan bahan kimia yang bersifat basa kuat dan digunakan di boiler untuk perawatan internal. Cairan $\mathrm{NaOH}$ bertujuan untuk mencegah terjadinya korosi dan kerak dalam boiler. Cairan $\mathrm{NaOH}$ dapat menyebabkan korosi pada pekerja maupun benda yang terkena dengan cairan ini.

Boiler merupakan bangunan dengan ketinggian lebih kurang 18 meter. Aktivitas di boiler terkadang menggunakan tangga maupun lift. Risiko yang dapat ditimbulkan oleh bahaya terjatuh dan terpeleset dari ketinggian berupa cedera dan dapat mengancam 
keselamatan pekerja. Potensi bahaya ini dapat dihindari dengan penggunaan APD pada pekerja.

\section{Penilaian Risiko}

Penilaian risiko bertujuan untuk mengetahui risiko bahaya yang dapat ditoleransi atau tidak dapat ditoleransi dan mengetahui tingkat risiko, sehingga dapat dilakukan kontrol. Hasil dari penilaian risiko pada area pengoperasian boiler adalah:

\section{Penilaian Pengendalian Risiko}

Penilaian pengendalian risiko bertujuan untuk mengetahui keefektifan dan implementasi dari pengendalian tersebut. PT. Indonesia Power
Unit Pembangkitan Semarang telah melakukan pengendalian berupa pengendalian teknik, pengendalian administratif, dan penyediaan APD (Alat Pelindung Diri). Pengendalian dilakukan agar dapat menurunkan risiko sampai batas teraman. Pengendalian teknik yang sudah dilakukan yaitu, terdapat perlengkapan pengaman pada boiler, penyediaan APAR, ventilasi pada area boiler, perawatan eksternal dan internal boiler, dan pengujian boiler. Pengendalian administratif berupa pelatihan terhadap operator, pengawasan supervisor, rotasi pekerjaan, instruksi kerja, penyediaan kotak P3K, dan safety sign. Penyediaan APD (Alat Pelindung Diri) yaitu safety shoes, safety helmt, ear plug, sarung tangan, dan masker.

Tabel 2. Penilaian Risiko pada Area Pengoperasian Boiler PT. Indonesia Power Unit Pembangkitan Semarang

\begin{tabular}{|c|c|c|c|c|c|}
\hline \multirow{2}{*}{ Langkah Pekerjaan } & \multirow{2}{*}{ Potensi Bahaya } & \multirow{2}{*}{ Risiko } & \multicolumn{2}{|c|}{$\begin{array}{l}\text { Penilaian Risiko } \\
\end{array}$} & \multirow{2}{*}{$\begin{array}{l}\text { Tingkat } \\
\text { Risiko }\end{array}$} \\
\hline & & & Likelihood & Severity & \\
\hline \multirow[t]{2}{*}{ Firing Boiler } & Cuaca panas & Dehidrasi & 1 & 2 & 2 \\
\hline & Ceceran minyak & Terpeleset & 2 & 2 & $\begin{array}{c}4 \\
\text { Low risk }\end{array}$ \\
\hline \multirow[t]{3}{*}{$\begin{array}{l}\text { Pengoperasian Peralatan } \\
\text { Boiler }\end{array}$} & Kebisingan & Tuli & 2 & 3 & $\begin{array}{c}6 \\
\text { Medium risk }\end{array}$ \\
\hline & Tekanan tinggi & Ledakan & 1 & 5 & $\begin{array}{c}5 \\
\text { High risk }\end{array}$ \\
\hline & $\begin{array}{l}\text { Kontak dengan pipa uap air } \\
\text { yang panas }\end{array}$ & Luka bakar & 1 & 2 & $\begin{array}{c}2 \\
\text { Low risk }\end{array}$ \\
\hline \multirow[t]{3}{*}{$\begin{array}{l}\text { Pengoperasian Force Draft } \\
\text { Fan/Gas Recirculation Fan }\end{array}$} & Kebisingan & Tuli & 2 & 3 & $\begin{array}{c}6 \\
\text { Medium risk }\end{array}$ \\
\hline & Arus Listrik & Kesetrum & 1 & 4 & $\begin{array}{c}4 \\
\text { Medium risk }\end{array}$ \\
\hline & Tangan terjepit & Cedera & 2 & 2 & $\begin{array}{c}4 \\
\text { Low risk }\end{array}$ \\
\hline Pengoperasian Pompa BBM & Ceceran minyak & Terpeleset & 2 & 2 & $\begin{array}{c}4 \\
\text { Low risk }\end{array}$ \\
\hline Pengisian Air Boiler & Kebisingan & Tuli & 2 & 3 & $\begin{array}{c}6 \\
\text { Medium risk }\end{array}$ \\
\hline Pengoperasian Burner & Percikan Api & Kebakaran & 2 & 2 & $\begin{array}{c}4 \\
\text { Low risk }\end{array}$ \\
\hline Pengoperasian Kimia & Terkena cairan $\mathrm{NaOH}$ & Korosi & 3 & 2 & $\begin{array}{c}6 \\
\text { Medium risk }\end{array}$ \\
\hline Pengoperasian Soot Blower & Bocoran uap air & Luka bakar & 3 & 4 & $\begin{array}{c}12 \\
\text { High risk }\end{array}$ \\
\hline \multirow[t]{2}{*}{ Pencatatan Parameter } & Terbentur & Cedera & 1 & 2 & $\begin{array}{c}2 \\
\text { Low risk }\end{array}$ \\
\hline & $\begin{array}{l}\text { Terjatuh dan terpeleset dari } \\
\text { ketinggian }\end{array}$ & Cedera & 2 & 4 & $\begin{array}{c}8 \\
\text { Medium } \\
\text { risk }\end{array}$ \\
\hline
\end{tabular}


Tabel 3. Penilaian Pengendalian Risiko pada Area Pengoperasian Boiler PT. Indonesia Power Unit Pembangkitan Semarang

\begin{tabular}{|c|c|c|c|c|c|c|}
\hline $\begin{array}{c}\text { Langkah } \\
\text { Pekerjaan }\end{array}$ & Potensi Bahaya & Risiko & $\begin{array}{c}\text { Tingkat } \\
\text { Risiko }\end{array}$ & Pengendalian & Implementasi & $\begin{array}{c}\text { Nilai } \\
\text { Kontrol }\end{array}$ \\
\hline \multirow[t]{2}{*}{ Firing Boiler } & Cuaca panas & Dehidrasi & $\begin{array}{l}2 \\
\text { Low risk }\end{array}$ & $\begin{array}{l}\text { Ventilasi ruangan } \\
\text { Safety sign } \\
\text { Penyediaan air minum }\end{array}$ & $\begin{array}{l}\text { Kontrol } \\
\text { diimplementasikan } \\
\text { sangat baik }\end{array}$ & $90 \%$ \\
\hline & Ceceran minyak & Terpeleset & $\begin{array}{l}4 \\
\text { Low risk }\end{array}$ & $\begin{array}{l}\text { Pembersihan lantai } \\
\text { Pemberian APD }\end{array}$ & $\begin{array}{l}\text { Kontrol } \\
\text { diimplementasikan } \\
\text { dengan baik }\end{array}$ & $75 \%$ \\
\hline \multirow[t]{3}{*}{$\begin{array}{l}\text { Pengoperasian } \\
\text { Peralatan } \\
\text { Boiler }\end{array}$} & Kebisingan & Tuli & $\begin{array}{l}6 \\
\text { Medium } \\
\text { risk }\end{array}$ & $\begin{array}{l}\text { Penyediaan APD } \\
\text { Safety Sign } \\
\text { Pengukuran intensitas } \\
\text { kebisingan }\end{array}$ & $\begin{array}{l}\text { Kontrol } \\
\text { diimplementasikan } \\
\text { cukup baik }\end{array}$ & $65 \%$ \\
\hline & Tekanan tinggi & Ledakan & $\begin{array}{l}5 \\
\text { High risk }\end{array}$ & $\begin{array}{l}\text { Safety valve } \\
\text { Pengawasan oleh supervisor } \\
\text { Instruksi kerja }\end{array}$ & $\begin{array}{l}\text { Kontrol } \\
\text { diimplementasikan } \\
\text { sangat baik }\end{array}$ & $90 \%$ \\
\hline & $\begin{array}{l}\text { Kontak dengan } \\
\text { pipa uap air } \\
\text { yang panas }\end{array}$ & Luka bakar & $\begin{array}{l}2 \\
\text { Low risk }\end{array}$ & $\begin{array}{l}\text { Pemberian APD } \\
\text { Safety sign } \\
\text { Penyediaan P3K }\end{array}$ & $\begin{array}{l}\text { Kontrol } \\
\text { diimplementasikan } \\
\text { dengan baik }\end{array}$ & $90 \%$ \\
\hline \multirow{3}{*}{$\begin{array}{l}\text { Pengoperasian } \\
\text { Force Draft } \\
\text { Fan/Gas } \\
\text { Recirculation } \\
\text { Fan }\end{array}$} & Kebisingan & Tuli & $\begin{array}{l}6 \\
\text { Medium } \\
\text { risk }\end{array}$ & $\begin{array}{l}\text { Penyediaan APD } \\
\text { Safety Sign } \\
\text { Pengukuran intensitas } \\
\text { kebisingan }\end{array}$ & $\begin{array}{l}\text { Kontrol } \\
\text { diimplementasikan } \\
\text { cukup baik }\end{array}$ & $65 \%$ \\
\hline & Arus Listrik & Kesetrum & $\begin{array}{l}4 \\
\text { Medium } \\
\text { risk }\end{array}$ & $\begin{array}{l}\text { Pemberian APD } \\
\text { Pemberian APAR }\end{array}$ & $\begin{array}{l}\text { Kontrol } \\
\text { diimplementasikan } \\
\text { sangat baik }\end{array}$ & $90 \%$ \\
\hline & Tangan terjepit & Cedera & $\begin{array}{l}4 \\
\text { Low risk }\end{array}$ & $\begin{array}{l}\text { Pemberian APD } \\
\text { Training }\end{array}$ & $\begin{array}{l}\text { Kontrol } \\
\text { diimplementasikan } \\
\text { sangat baik }\end{array}$ & $90 \%$ \\
\hline $\begin{array}{l}\text { Pengoperasian } \\
\text { Pompa BBM }\end{array}$ & Ceceran minyak & Terpeleset & $\begin{array}{l}4 \\
\text { Low risk }\end{array}$ & $\begin{array}{l}\text { Pembersihan lantai } \\
\text { Pemberian APD }\end{array}$ & $\begin{array}{l}\text { Kontrol } \\
\text { diimplementasikan } \\
\text { dengan baik }\end{array}$ & $75 \%$ \\
\hline $\begin{array}{l}\text { Pengisian Air } \\
\text { Boiler }\end{array}$ & Kebisingan & Tuli & $\begin{array}{l}6 \\
\text { Medium } \\
\text { risk }\end{array}$ & $\begin{array}{l}\text { Penyediaan APD } \\
\text { Safety Sign } \\
\text { Pengukuran intensitas } \\
\text { kebisingan }\end{array}$ & $\begin{array}{l}\text { Kontrol } \\
\text { diimplementasikan } \\
\text { cukup baik }\end{array}$ & $65 \%$ \\
\hline $\begin{array}{l}\text { Pengoperasian } \\
\text { Burner }\end{array}$ & Percikan Api & Kebakaran & $\begin{array}{l}4 \\
\text { Low risk }\end{array}$ & $\begin{array}{l}\text { Penyediaan APD } \\
\text { Penyediaan APAR } \\
\text { Pengawasan oleh supervisor } \\
\text { Instruksi kerja } \\
\text { Perawatan sarana }\end{array}$ & $\begin{array}{l}\text { Kontrol } \\
\text { diimplementasikan } \\
\text { cukup baik }\end{array}$ & $65 \%$ \\
\hline $\begin{array}{l}\text { Pengoperasian } \\
\text { Kimia }\end{array}$ & $\begin{array}{l}\text { Terkena cairan } \\
\mathrm{NaOH}\end{array}$ & Korosi & $\begin{array}{l}6 \\
\text { Medium } \\
\text { risk }\end{array}$ & $\begin{array}{l}\text { Penyediaan APD } \\
\text { Penyediaan P3K } \\
\text { Instruksi kerja } \\
\text { Pengawasan oleh supervisor }\end{array}$ & $\begin{array}{l}\text { Kontrol } \\
\text { diimplementasikan } \\
\text { dengan baik }\end{array}$ & $65 \%$ \\
\hline $\begin{array}{l}\text { Pengoperasian } \\
\text { Soot Blower }\end{array}$ & $\begin{array}{l}\text { Bocoran uap } \\
\text { air } \\
\left(\text { suhu }>500^{\circ} \mathrm{C}\right)\end{array}$ & Luka bakar & $\begin{array}{l}12 \\
\text { High risk }\end{array}$ & $\begin{array}{l}\text { Penyediaan APD } \\
\text { Penyediaan APAR } \\
\text { Pengawasan oleh supervisor } \\
\text { Instruksi kerja } \\
\text { Perawatan sarana }\end{array}$ & $\begin{array}{l}\text { Kontrol } \\
\text { diimplementasikan } \\
\text { dengan baik }\end{array}$ & $75 \%$ \\
\hline \multirow[t]{2}{*}{$\begin{array}{l}\text { Pencatatan } \\
\text { Parameter }\end{array}$} & Terbentur & Cedera & $\begin{array}{l}2 \\
\text { Low risk }\end{array}$ & $\begin{array}{l}\text { Pemberian APD } \\
\text { Training }\end{array}$ & $\begin{array}{l}\text { Kontrol } \\
\text { diimplementasikan } \\
\text { sangat baik }\end{array}$ & $90 \%$ \\
\hline & $\begin{array}{l}\text { Terjatuh dan } \\
\text { terpeleset dari } \\
\text { ketinggian }\end{array}$ & Cedera & $\begin{array}{l}8 \\
\text { Medium } \\
\text { risk }\end{array}$ & $\begin{array}{l}\text { Pemberian APD } \\
\text { Training }\end{array}$ & $\begin{array}{l}\text { Kontrol } \\
\text { diimplementasikan } \\
\text { dengan baik }\end{array}$ & $75 \%$ \\
\hline
\end{tabular}




\section{Penilaian Risiko Sisa}

Tujuan melakukan penelitian risiko sisa agar dapat menurunkan risiko sebelumnya dengan melakukan penilaian pengendalian risiko, sehingga risiko dapat secara utuh diterima. Rumus perhitungan risiko sisa sebagai berikut (Siswanto, 2009):

$$
\frac{(100 \%-\% \text { nilai kontrol }) \times \text { risiko murni }}{100 \%}
$$

Secara keseluruhan penilaian risiko sisa pada area pengoperasian boiler PT. Indonesia Power Unit Pembangkitan Semarang didapatkan kategori rendah ke tidak ada risiko sebanyak 4 bahaya, dari kategori medium ke tidak ada risiko sebanyak 1 bahaya, dari kategori medium ke rendah sebanyak 3 bahaya, dari kategori tinggi ke rendah sebanyak 2 bahaya, dan kategoti tetap rendah sebanyak 2 bahaya.

\section{PEMBAHASAN}

Berikut ini merupakan uraian hasil temuan 12 bahaya pada risk assessment terhadap area pengoperasian boiler PT. Indonesia Power Unit Pembangkitan Semarang. Pada area pengoperasian boiler memungkinkan pekerja terpapar kebisingan dengan intensitas 80-100 dBA. Bahaya kebisingan jarang terjadi karena pekerja menggunakan APD, sehingga nilai likelihood adalah 2 (unlikely). Kebisingan dapat menyebabkan ketulian. Apabila terpapar secara terus menerus dapat menurunkan daya pendengaran, oleh karena itu nilai severity adalah 3 (Moderate). Tingkat risiko kebisingan adalah 6 (medium risk). Risiko ini dapat dikurangi karena sudah terdapat pengendalian berupa penyediaan APD (ear plug), pemberian safety sign, dan pengukuran intensitas kebisingan. Pengendalian kebisingan diperoleh nilai kontrol $65 \%$, sehingga nilai risiko sisa 2 dengan kategori low risk.

Pada area pengoperasian boiler, memungkinkan pekerja terpapar cuaca panas, namun pada area pengoperasian boiler terdapat ruang kontrol yang ber-AC. Penelitian yang dilakukan oleh Tawatsupa dkk di Thailand, menemukan hampir 20\% dari responden mengalami paparan panas, sehingga nilai likelihood adalah 1 (rare). Bekerja dicuaca panas dapat menyebabkan kelelahan tubuh dan dehidrasi, sehingga nilai severity adalah 2 (minor). Tingkat risiko untuk cuaca panas adalah 2 (low risk). Tingkat risiko ini dapat dikurangi karena mengingat terdapat ruang kontrol yang ber-AC dan pemberian safety sign di sekitar area. Pengendalian tersebut mendapat nilai kontrol $90 \%$. Nilai risiko sisa pada cuaca panas 0 dengan kategori no risk.

Pada area pengoperasian boiler, memungkinkan terdapat ceceran minyak, sehingga nilai Likelihood adalah 2 (unlikely). Ceceran minyak dapat menyebabkan risiko terpeleset, sehingga nilai severity adalah 2 (minor). Tingkat risiko untuk ceceran minyak adalah 4 (low risk). Tingkat risiko ini dapat dikurangi karena mengingat terdapat pengendalian berupa pembersihan lantai dan pemakaian safety shoes. Pengendalian pada ceceran minyak mendapatkan nilai kontrol $75 \%$. Nilai risiko sisa pada ceceran minyak 1 dengan kategori low risk.

Pada dasarnya, uap mempunyai tekanan uap dan pada pengoperasian boiler dapat menimbulkan tekanan tinggi. Boiler selalu bekerja pada tekanan yang tinggi dari tekanan yang diperlukan (Darmanto, S., Rahmat, dan Setyoko, B., 2007). Tekanan tinggi yang melebihi kapasitas akan menyebabkan uap dibuang melalui safety valve, sehingga tekanan akan menjadi normal. Nilai Likelihood tekanan tinggi adalah 1 (rare). Tekanan tinggi dapat menyebabkan ledakan, sehingga nilai severity adalah 5 (outstanding). Tingkat risiko untuk tekanan tinggi adalah 5 (high risk). Tingkat risiko ini dapat dikurangi karena mengingat terdapat pengendalian teknik berupa safety valve. Pengendalian tekanan tinggi mendapatkan nilai kontrol $0 \%$ dan nilai risiko sisa 1 dengan kategori low risk.

Pada pengoperasian boiler, jarang terjadi bahaya berupa kontak dengan pipa uap air yang panas hal ini dikarenakan pekerja telah menggunakan APD, sehingga nilai Likelihood adalah 1 (rare). Kontak dengan pipa uap air yang panas dapat menyebabkan luka bakar, sehingga nilai severity adalah 2 (minor). Tingkat risiko ini dapat dikurangi karena mengingat terdapat pengendalian berupa pemberian APD, safety sign, dan penyediaan P3K. Pengendalian tersebut diperoleh nilai kontrol $90 \%$ dan nilai risiko sisa 0 dengan kategori no risk.

Pada area pengoperasian boiler memungkinkan pekerja terkena arus listrik karena banyaknya kabel yang berserakan. Bahaya tersebut hampir tidak pernah terjadi karena kabel sudah telapisi oleh isolator, sehingga nilai Likelihood adalah 1 (rare). Arus listrik dapat menyebabkan kesetrum hingga berujung kematian tergantung dari kuat arus dari listrik tersebut, sehingga nilai severity adalah 4 (major). Tingkat risiko untuk arus listrik adalah 4 (medium risk). Tingkat risiko ini dapat dikurangi karena mengingat terdapat pengendalian 
berupa pemberian APD dan APAR di sekitar pengoperasian peralatan boiler. Pengendalian arus listrik memperoleh nilai kontrol $90 \%$, dan nilai risiko sisa 0 dengan kategori no risk.

Pada area pengoperasian boiler jarang terjadi risiko berupa tangan terjepit, namun hal ini dapat saja terjadi apabila pekerja tidak berkonsentrasi. Nilai Likelihood pada risiko tangan terjepit adalah 2 (unlikely). Terjepit dapat menyebabkan cedera tangan, sehingga nilai severity adalah 2 (minor). Tingkat risiko untuk tangan terjepit adalah 4 (medium risk). Tingkat risiko ini dapat dikurangi karena mengingat terdapat pengendalian berupa pemberian APD dan training bagi pekerja. Pengendalian risiko tersebut diperoleh nilai kontrol $90 \%$ dengan nilai risiko sisa 0 dengan kategori no risk.

Pada saat pengoperasian boiler memungkinkan adanya percikan api yang keluar. Bahan bakar yang digunakan adalah MFO sehingga akan sulit untuk terbakar. Nilai likelihood pada percikan api adalah 2 (unlikely). Percikan api dapat menyebabkan kebakaran kecil di sekitar pengoperasian alat pembakar, sehingga nilai severity adalah 2 (minor). Tingkat risiko untuk percikan api adalah 4 (low risk). Tingkat risiko ini dapat dikurangi karena sudah terdapat pengendalian berupa penyediaan APAR, penyediaan APD, dan perawatan sarana. Pengendalian tersebut diperoleh nilai kontrol $65 \%$ dengan nilai risiko sisa 1 dengan kategori low risk.

Pada pengoperasian boiler memungkinkan pekerja terkena bocoran uap air. hal ini dapat terjadi karena pipa superheater pernah mengalami kebocoran, sehingga nilai likelihood adalah 3 (possible). Terkena bocoran uap air yang bersuhu $>500^{\circ} \mathrm{C}$ dapat menyebabkan luka bakar sampai berujung kematian, sehingga nilai severity adalah 4 (major). Tingkat risiko untuk bocoran uap air adalah 12 (high risk). Tingkat risiko ini dapat dikurangi karena mengingat terdapat pengendalian berupa perawatan sarana dan penyediaan APD. Pengendalian tersebut diperoleh nilai kontrol $75 \%$ dengan nilai risiko sisa 3 dengan kategori low risk.

Pada area pengoperasian boiler memungkinkan terkena benturan, karena banyaknya peralatan di boiler. Pekerja di PT. Indonesia Power Unit Pembangkitan Semarang menyediakan APD berupa safety helmt, sehingga nilai Likelihood adalah 2 (unlikely). Terbentur dapat mengakibatkan cedera yang memerlukan perawatan medis namun tidak menimbulkan kerugian yang besar, sehingga nilai severity adalah 2 (minor). Tingkat risiko untuk tangan terjepit adalah 4 (low risk). Tingkat risiko ini dapat dikurangi karena mengingat terdapat pengendalian berupa pemberian APD dan training bagi pekerja. Pengendalian tersebut memperoleh nilai kontrol $90 \%$ dan nilai risiko sisa 0 dengan kategori no risk.

Pada pengoperasian boiler memungkinkan pekerja terkena cairan $\mathrm{NaOH}$. Dari hasil observasi pekerja operator di boiler PT. Indonesia Power Unit Pembangkitan Semarang tidak mengetahui bahan kimia yang digunakan sebagai perawatan internal boiler. Nilai Likelihood pada terkena cairan $\mathrm{NaOH}$ adalah 3 (possible). Terkena cairan $\mathrm{NaOH}$ dapat mengakibatkan korosi, sehingga nilai severity adalah 2 (minor). Tingkat risiko untuk ceceran minyak adalah 6 (medium risk). Tingkat risiko ini dapat dikurangi karena mengingat terdapat pengendalian berupa penyediaan APD, P3K dan instruksi kerja. Pengendalian tersebut memperoleh nilai kontrol 65\% dan nilai risiko sisa 2 dengan kategori low risk.

Pada area pengoperasian boiler memungkinkan pekerja untuk terjatuh dan terpeleset dari ketinggian, karena terdapat beberapa pekerjaan yang dilakukan diketinggian. Bahaya tersebut jarang karena pekerja sudah menggunakan APD, sehingga nilai Likelihood adalah 3 (possible). Terjatuh dan terpeleset dari ketinggian dapat mengakibatkan cedera, luka memar, dan dapat meninggal, sehingga nilai severity adalah 4 (major). Tingkat risiko untuk tangan terjepit adalah 8 (medium risk). Tingkat risiko ini dapat dikurangi karena mengingat terdapat pengendalian berupa pemberian APD dan training bagi pekerja. Pengendalian tersebut memperoleh nilai kontrol $75 \%$ dengan nilai risiko sisa 2 dengan kategori low risk.

\section{SIMPULAN}

Boiler PT. Indonesia Power Unit Pembangkitan Semarang berjumlah 3 unit dengan jenis pipa air dengan menggunakan MFO dan HSD. Bahaya yang teridentifikasi pada area pengoperasian boiler PT. Indonesia Power Unit Pembangkitan Semarang berjumlah 12 bahaya. Penilaian risiko pada pengoperasian boiler PT. Indonesia Power Unit Pembangkitan Semarang didapatkan 6 kategori low risk, 4 kategori medium risk, dan 2 kategori high risk. Penilaian pengendalian risiko pada pengoperasian boiler PT. Indonesia Power Unit Pembangkitan Semarang didapatkan 6 bahaya kategori nilai kontrol sangat baik, 3 bahaya kategori nilai kontrol diimplementasikan dengan baik, dan 3 bahaya kategori nilai kontrol diimplementasikan 
dengan cukup baik. Penilaian risiko sisa pada pengoperasian boiler PT. Indonesia Power Unit Pembangkitan Semarang didapatkan 5 risiko sisa kategori no risk, dan 7 risiko sisa kategori low risk. Saran untuk perusahaan sebaiknya perusahaan melakukan pemeliharaan pada pipa di boiler agar bahaya bocoran uap air tidak menjadi lebih besar, perketat pengawasan, dan melakukan pengendalian untuk menurunkan angka likelihood sampai batas terendah.

\section{DAFTAR PUSTAKA}

Australian/New Zealand Standard, AS/NZS 4360. 2004. Risk Management Standards. New Zealand: Council of Standards Australia and Council of Standards.

Darmanto, S., Rahmat., Setyoko, B., 2007. Peluang Penghematan Energi Uap Menggunakan Metode Non-Investment Point. Jurnal unimus.ac.id, 5(1): 35-40.

Departemen Tenaga Kerja dan Transmigrasi RI. 1970. Undang-Undang No. 1 Tahun 1970 Tentang Keselamatan Kerja.

Departemen Tenaga Kerja dan Transmigrasi RI. 1930. Peraturan Uap.

Fatoni, R. 2013. Rekomendasi Standar Sistem Keselamatan untuk Steam Boiler di Pabrik Tahu. Simposium Nasional Teknologi Terapan(SNTT), ISSN 2339-028X.
Fauzy., Rusdhianto, E., 2012. Desain Kontroler PID Fuzzy Untuk Pengendalian Tekanan dan Level Oksigen Gas Buang pada Boiler. Jurnal Teknik POMITS, 1(1):1-6.

Kristianingsih, L., Ali, M. 2013. Analisis Safety System dan Manajemen Risiko pada Steam Boiler PLTU di Unit 5 Pembangkitan Paiton, PT. YTL. Jurnal Teknik POMITS, 2(2): 356-361.

PT. Indonesia Power Unit Pembangkitan Semarang. 2003. Gambaran Umum Perusahaan Indonesia Power. Semarang : PT Indonesia Power UP semarang.

Radiyan, M. 2014. Risk Assessment and Risk Management pada Pengoperasian Pesawat Uap di PT Japfa Comfeed Indonesia Tbk Unit Gedangan. Tugas Akhir. Surabaya: Universitas Airlangga.

Rambe, A. 2003. Gangguan Pendengaran Akibat Bising. Jurnal kedokteran. Sumatera Utara: Universitas Sumatera Utara.

Siswanto, A. 2009. Risk Management. Surabaya: Balai Hiperkes dan Keselamatan Kerja Jawa Timur.

Tawatsupa, B., dkk., 2012. Association Between Heat Stress And Occupational Injury Among Thai Workers: Findings of The Thai Cohort Study. Industrial Health Journal [Online Journal] 2012; [Sitasi 25 Juni 2016] http://www.jniosh.go.jp/en/ indu_hel/pdf/IH_51_1_34.pdf.

Veasey, D., Lisa C., Barbara M. 2002. Confined Space Entry and Emergency Response. United States of America: The McGraw-Hill Compenies, Inc. 